\title{
Microbial Biotextiles for a Circular Materials Economy
}

Authors: Theanne N. Schiros ${ }^{1,2}+*$, Romare Antrobus ${ }^{3} \uparrow$, Delfina Farias ${ }^{1}$, Yueh-Ting Chiu ${ }^{3}$, Christian Tay Joseph ${ }^{2}$, Shanece Esdaille ${ }^{2}$, Gwen Karen Sanchiricco ${ }^{1}$, Grace Miquelon ${ }^{1}$, Dong $\mathrm{An}^{4}$, Sebastian T. Russell ${ }^{4}$, Adrian M. Chitu ${ }^{5}$, Susanne Goetz ${ }^{6}$, Anne Marika Verploegh Chassé ${ }^{7}$, Colin Nuckolls ${ }^{8}$, Sanat K. Kumar ${ }^{4}$, and Helen H. Lu

\section{Affiliations:}

${ }^{1}$ Department of Science and Mathematics, Fashion Institute of Technology; New York, NY 10001.

${ }^{2}$ Materials Research Science and Engineering Center, Columbia University; New York, NY 10027.

${ }^{3}$ Department of Biomedical Engineering, Columbia University; New York, NY 10027.

${ }^{4}$ Department of Chemical Engineering, Columbia University; New York, NY 10027.

${ }^{5}$ Materials Science and Engineering, Columbia University; New York, NY 10027.

${ }^{6}$ Surface/Textile Design, Fashion Institute of Technology; New York, NY 10001.

${ }^{7}$ Footwear and Accessories Design, Fashion Institute of Technology; New York, NY 10001.

${ }^{8}$ Department of Chemistry, Columbia University, New York, NY 10027.

$\uparrow$ These authors contributed equally to this work.

*Co-corresponding authors. Email: ts2526@columbia.edu, hhlu@ columbia.edu

Abstract: Harnessing microbial biofabrication and inspired by indigenous practices, we engineer high-performance microbial nanocellulose (MC) biotextiles with a sustainable circular life cycle. Specifically, our plant-based lecithin phosphocholine treatment modulates cellulose crosslinking through phosphate and methylene groups, to yield a biodegradable material with superior mechanical and flame-retardant properties. Coloration is achieved using natural dyes and wasteto-resource strategies. Life cycle impact assessment reveals MC biotextiles mitigate the carcinogenics of leather by a factor of $10^{3}$ and the carbon footprint of synthetic leather and cotton by $\sim 97 \%$, for widespread application in fashion, interiors, and construction. The translational potential of this approach is tremendous, as using microbes and green chemistry to engineer regenerative, high-performance products will disrupt linear production models and mitigate its environmental threats in a circular economy.

One-Sentence Summary: We engineer high-performance, microbial biotextiles which mitigate the climate and toxicity impacts of conventional textiles. 
bioRxiv preprint doi: https://doi.org/10.1101/2021.09.22.461422; this version posted September 24, 2021. The copyright holder for this preprint

(which was not certified by peer review) is the author/funder. All rights reserved. No reuse allowed without permission.

Submitted Manuscript

September 2021

The linear economy that has been the dominant production model since the Industrial Revolution drives climate instability and threatens ecological and human health. The textile industry, in particular, is reliant on industrial agriculture for cellulosic fibers (1), nonrenewable petrochemicals to produce synthetic fibers, dyes, tanning and finishing agents, and chemically and energy intensive processing (2). It is responsible for $10 \%$ of global carbon emissions (3), $20 \%$ of global waste water (4), $35 \%$ of marine microplastic pollution (5), and expected to use $25 \%$ of the global carbon budget by 2050 (6). For instance, chrome tanning leather creates large volumes of mutagenic, teratogenic, and carcinogenic chemical pollution, such that tannery effluents rank as the highest pollutants among all industrial wastes (7). Leather alternatives created from petrochemical-based textiles and coatings have emerged. However, these materials are not biodegradable, contain endocrine-disrupting chemicals, and shed nano- and micro-plastics, which absorb and accumulate persistent organic pollutants. Microplastics have been found in the intestines of marine animals and humans, and, recently, in human placenta (8-9). Thus, there is a pressing need for new fabrication strategies that minimize and close material and energy loops in a regenerative, circular economy, to make industrialization compatible with nature and sustainable global development.

This challenge has motivated a search for more sustainable, bio-based textiles, especially leather alternatives (10), including mycelium and pineapple leather, and gene editing of yeast to produce collagen. Microbial nanocellulose (MC) is a highly crystalline biopolymer produced extracellularly by bacteria, one of the most promising in terms of cellulose yield being Acetobacter xylinus (11). Under aerobic conditions, these bacteria biosynthesize extracellular cellulose nanofibrils (10-100 nm diameter) that self-assemble into a three-dimensional layered pellicle with high water content $(>98 \%)$ at the air-media interface under static conditions.

The bottom-up assembly of MC offers unique advantages to tune and meet key design criteria - rapid renewability, low toxicity, scalability, performance, and compostability — for multi-functional, circular economy textiles. Although identical in chemical structure to plant-based cellulose, $\mathrm{MC}$ is distinctly characterized by its readily extractable nanofiber network, degradability, excellent tensile strength due to high degrees of polymerization and crystallinity (80-90\%), and the possibility to control these and other physical properties including porosity during biosynthesis (12). Importantly, MC can offer a rapidly renewable raw material for textiles while eliminating the land, water and chemicals usage of production of agricultural (13) and wood pulp cellulose (14). For instance, the amount of cellulose produced by eucalyptus in a $10,000 \mathrm{~m}^{2}$ area of land over 7 years could be achieved at higher purity by microbial fermentation in a $500 \mathrm{~m}^{3}$ bioreactor in 22 days (15).

However, like many naturally occurring biopolymers, including the aforementioned biobased leather alternatives, the hygroscopicity of as-fabricated MC results in a brittleness that hinders translation to textile applications (16). Strategies to stabilize the mechanical properties of these materials typically involve heavy metals and/or synthetic plasticizers and coatings which compromise material biodegradability, introduce human and ecological toxicity, and increase flammability (17), making development of innovative green processing a major research priority.

Yet, for millennia, societies around the world have created durable, water-repellent leather using non-toxic tanning methods, including brain and organ tanning followed by smoke tanning, dating back at least 5,000 years to "Ötzi" (Iceman) (18). Unfortunately, much of these ancient methods have been lost, and the mechanism and underlying chemistry of fat tanning is not fully understood. It has been proposed that braining and smoking hides are forms of aldehyde tanning, in which the aldehyde carbon reacts with the amine nitrogen of collagen to produce an imine 
bioRxiv preprint doi: https://doi.org/10.1101/2021.09.22.461422; this version posted September 24, 2021. The copyright holder for this preprint

(which was not certified by peer review) is the author/funder. All rights reserved. No reuse allowed without permission.

Submitted Manuscript

September 2021

product, which reacts with an amine on a neighboring polypeptide to covalently cross-link the collagen into leather (19). Brain tissue is high in fatty acids and lecithin. The lipid portion of lecithin molecules polarize away from water in the emulsion, while the phosphate and choline groups are attracted to it, stabilizing the tanning emulsion and facilitating interaction between the oils and collagen.

Inspired by these ancient practices, we hypothesize that lecithin phosphatidylcholine will modify the cross-linking and material properties of MC through its hydrophilic -OH groups to make it suitable for use as a bioleather. An increase in ductility of MC with application of traditional brain and smoke tanning processes provided a positive control to further encourage this line of investigation (Fig. s1). Following a bottom-up approach of microbial biosynthesis of nanocellulose coupled to a plant-based lecithin tanning emulsion, we create a high performance bioleather that exhibits high tensile strength, ductility, and outstanding flame retardance, and soil biodegradability (Fig. 1). Here, a symbiotic colony of Acetobacter and yeast (SCOBY) metabolizes sugars into cellulose nanofibers via enzymatic pathways (12). A variety of carbon sources, such as glucose, fructose, and sucrose, which may be extracted from agro-industrial byproducts, can be utilized for scalable production of MC (Movie s1). A range of colors and design motifs are achieved using historically important natural dyes and waste-to-resource strategies, offering a non-toxic alternative to the brown color resulting from the Maillard reaction when MC is produced in a SCOBY. Tailoring the shape of the cultivation vessel to the pattern geometry enables zero waste production, as shown for our biodegradable, bioleather bag prototypes (Fig. 1). The microbial bioleather created here meets key criteria for a circular material economy, including renewability, low toxicity, functional and environmental performance, biodegradability and scalability.

\section{Results and Discussion}

\section{Physical and Mechanical Properties with Lecithin Treatment}

We investigated the effect of lecithin treated on MC, as well as an aldehyde smoke treatment, as documented for brain tanning of hides in order to complete the conversion to leather. As-fabricated, lecithin "tanned", aldehyde tanned (smoked), and lecithin and aldehyde tanned MC are denoted MC, LT, S, and LTS, respectively. A dense, three-dimensional network of unaligned, intertwined nanofibers is observed with scanning electron microscopy (SEM) on MC surfaces before and after processing (Fig. 2A). Treatment with lecithin and aldehyde tanning, separately and sequentially, yielded no significant differences in fiber size relative to as-fabricated MC (average diameter of $71.00 \pm 19.00 \mathrm{~nm}$, Table 1). This indicates that the emulsion does not coat the fibers but is rather removed with rinsing. However, compositional analysis with energy dispersive $\mathrm{x}$-ray measured nearly four times higher phosphorous concentration than the MC control $(2.02 \%$ vs. $0.57 \%, \wedge p<0.05, n=3)$, supporting the favorability of interaction between the phosphocholine group of lecithin with cellulose (Fig. s2).

40 Common to unprocessed biopolymers, as-fabricated MC exhibits varied stress-strain profiles under uniaxial tensile testing (Fig. 2B). The typical trade-off between tensile strength and ductility, the latter a reflection of flexibility which considers both the strain at yield point and toughness, is apparent for dried MC. Despite the same biosynthesis and processing parameters, MC exhibits elastic moduli ranging from $58.30 \pm 35.71$ to $210.91 \pm 58.61 \mathrm{MPa}$ for MC1 (high tensile strength, brittle) and MC 2 (lower tensile strength, greater ductility), respectively (Table 1). Without lecithin treatment, smoked (S) samples also have variable mechanical properties. Lecithin tanning stabilizes the mechanical properties and increases the elastic modulus, toughness, and 
bioRxiv preprint doi: https://doi.org/10.1101/2021.09.22.461422; this version posted September 24, 2021. The copyright holder for this preprint

(which was not certified by peer review) is the author/funder. All rights reserved. No reuse allowed without permission.

Submitted Manuscript

September 2021

maximum stress $(\wedge \mathrm{p}<0.05, \mathrm{n}=4)$ of the material; LT group exhibits higher tensile strength than leather or cotton up to strain values of $33 \%$ and $45 \%$, respectively (Fig. 2B). Surprisingly, the superior mechanical properties of LT are not reflected in the bulk microstructure as probed with x-ray diffraction (Fig. 2C). The (1-10), (110) and (200) Bragg peaks of cellulose I are largely unaffected by lecithin tanning, with only a minor increase in crystallinity index $(87 \%$ vs $84 \%$, Table 1), calculated using a peak deconvolution method (20), and unchanged d-spacing and similar crystalline domain size relative to MC (Table s1). A similar increase in tensile strength and ductility unaccompanied by changes in microstructure has been observed for phosphorylated cellulose with low phosphorus concentrations comparable to those measured for LT (21).

\section{Flame retardance due to lecithin tanning and unique self-organization of MC nanofibers}

Flame-retardance is an important design criterion for performance textiles, but industrial flame-retardant chemicals are considered hazardous substances linked to autoimmune diseases, learning disabilities, neurological and reproductive problems, birth defects, and cancer (22). Since phosphorous compounds are effective in reducing biopolymer flammability (23), phosphorylation with LT led us to investigate the flame retardance of MC biotextiles. Remarkably, when exposed to a direct $2054^{\circ} \mathrm{C}$ flame, LT biotextiles do not ignite (Fig. 3A). After 40 seconds a control aluminum brazing rod melts within seconds of application of the flame, while the biotextile continues to deflect the flame, without propagation. LT samples were then repeatedly exposed to the direct flame until surface char formation was observed. Moreover, just below the easily removable surface char, the bulk LT biotextile remained intact, underscoring its outstanding flameretardant capacity (Fig. 3A).

Analysis of the thermal stability and decomposition behavior of as-fabricated and treated biotextiles provide insights on the mechanism of flame retardance. Thermogravimetric analysis (TGA) and dTGA curves (Fig. 3B) show a three-step mass loss, representing: (I) the initial evaporation of free and bound water between $25-200^{\circ} \mathrm{C}$; (II-III) polymer decomposition (210$240^{\circ} \mathrm{C}$ ); and (IV) the production of either pyrolysis-based levoglucosan or flame-resistant char $\left(300-360^{\circ} \mathrm{C}\right)$. Higher mass loss is observed for LT relative to $\mathrm{MC}$ in regions I-III: $8.50 \pm 0.25 \%$ vs $5.38 \pm 0.87 \%$ at $150{ }^{\circ} \mathrm{C}$ (region I); $29.55 \pm 0.25$ vs $16.96 \pm 2.37 \%$ at $232{ }^{\circ} \mathrm{C}$ (region II) and $58.99 \pm 0.55 \%$ vs $49.51 \pm 1.21 \%$ at $340^{\circ} \mathrm{C}$ (region III). Finally, a lower decomposition temperature onset is also observed for $\mathrm{L}$, and aliphatic compounds are decomposed into char with a greater residual mass for $\mathrm{LT}$ than $\mathrm{MC}$ at $680^{\circ} \mathrm{C}(18.18 \%$ vs $8.99 \%)$.

The data indicates that lecithin treatment lowers the decomposition temperature of $\mathrm{MC}$ and redirects the combustion pathway from formation of levoglucosan towards formation of foaming char as an insulating oxygen barrier, resulting in the outstanding flame resistance. This is attributed to the addition of phosphorous compounds with lecithin tanning, which promotes dehydration to yield unsaturated compounds that polymerize at high temperatures to a cross-linked, intumescent foaming char.

Note that the as-fabricated MC also demonstrates a degree of flame retardance, which may be a consequence of the nanoscale self-organization of MC fibers into a layered structure, visible under the deflected flame (Fig. 3A). To investigate the influence of the layered microstructure on flame retardance, as-fabricated MC samples of varying thickness were obtained by removing layers from a hydrated MC pellicle (45 cm x $54 \mathrm{~cm}, 2.5 \mathrm{~cm}$ thick, Fig. s3), drying under ambient conditions, and flame testing (Fig. 3C). The MC mass lost to combustion decreased with increasing (hydrated state) thickness until $2.5 \mathrm{~cm}$, beyond which point MC material loss was minimal, although more material was lost than for LT of the same thickness (Fig. 3A, C).

The formation of intumescent bubbles on the nanofiber surface exposed to the flame is observed in the charred portion of LT, as well as for untreated MC of sufficient thickness $(\geq 2.5$ 
bioRxiv preprint doi: https://doi.org/10.1101/2021.09.22.461422; this version posted September 24, 2021. The copyright holder for this preprint (which was not certified by peer review) is the author/funder. All rights reserved. No reuse allowed without permission.

Submitted Manuscript

September 2021

$\mathrm{cm}$ ), in high magnification SEM images (Fig. 3D). The multi-layer structure of MC mimics that of a multilayer nanocoating, well known as physical surface barriers that limit heat and oxygen transfer between the fire and cellulose, while the densely packed arrangement of MC nanofibers further limits oxygen available to support a flame. Bubble formation is accompanied by generation of water vapor, which favors production of an insulating foaming char barrier, that in turn, prevents combustion by reducing heat transmission to the MC surface, and inhibiting oxygen and combustible volatiles from diffusing to the flame.

To further investigate the effect of the layered structure of MC on flame response, we attempted to disrupt it by blending MC into a slurry and casting it into a film. We note that the MC nanofiber morphology drives self-assembly into a hydrogen-bonded sheet during dehydration without chemical intervention. Surprisingly, while combusting more readily than as-fabricated $\mathrm{MC}$, the cast film also demonstrated a degree of flame resistance. Electron micrographs of the cross-sections of the films revealed that blended MC self-organized to recover the original layered structure with the nanofiber morphology intact (Fig. s4). Thus, in contrast to the ignitable behavior of plant-based cellulose, the unique nano- and microscale assembly of MC, and in the case of LT, modified chemical properties, imbue the material with non-toxic flame retardance.

\section{Chemical mechanism underlying improved mechanical performance}

Molecular level insights on the chemical origin of the improved mechanical properties for LT biotextiles are revealed by x-ray photoelectron (XPS) and infra-red (FTIR) spectroscopy. A peak centered at $134 \mathrm{eV}$ in the phosphorous (P 2p) XPS (Fig. 4A) indicates that lecithin tanning introduces phosphorus in oxidized form. Carbon 1s XPS reveals an increase in carboxyls, esters and anhydrides, observed at binding energies of 286.6 (C-O-H), 288.1 (C-O-C), and $289.1 \mathrm{eV}$ ($\mathrm{COOR})$, respectively (24). These chemical groups, along with $\mathrm{P}=\mathrm{O}(530.9 \mathrm{eV})$ and $\mathrm{C}-\mathrm{O}-\mathrm{P}$ bonds (533.5 eV) (25), also modify the O 1s XPS after lecithin tanning (Fig. 4A).

Chemical fingerprints of bonding observed with FTIR provide mechanistic insights on modulation of cellulose cross-linking with lecithin tanning (Fig. 4B). New peaks representative of phosphated cellulose appear for LT, including $\mathrm{P}=\mathrm{O}$ resonances at $1207.4,1230$ and $1252 \mathrm{~cm}^{1}$, and a $-\mathrm{P}-\mathrm{OH}$ stretch vibration at $898 \mathrm{~cm}^{-1}$ (25-27). Further, enhancement of -OH vibrational peaks characteristic of the cellulose skeleton at $3450-3000 \mathrm{~cm}^{1}$ and $664 \mathrm{~cm}^{-1}$, and methyl and methylene resonances, including $\mathrm{C}-\mathrm{H}$ vibrational bands at $1437-1245 \mathrm{~cm}^{-1}$ and $3000-2853 \mathrm{~cm}^{-1}$ and the C$\mathrm{H}$ deformation (1428, 1370 and $\left.1316 \mathrm{~cm}^{-1}\right), \mathrm{CH}_{2}\left(1184-1104 \mathrm{~cm}^{-1}\right)$ and $\mathrm{C}-\mathrm{O}-\mathrm{H}$ groups $\left(690 \mathrm{~cm}^{-1}\right)$ is observed for LT relative to MC (26-28). FTIR peak ratios, expressed as the Lateral Order Index (LOI) (29), shows a higher degree of overall order for LT compared to MC throughout the bulk of the material (Table s4, Fig. s5).

Collectively, the data suggests that the lecithin-phosphatidylcholine treatment modifies cellulose cross-linking through phosphate, exocyclic $\mathrm{CH}_{2}$ and carboxyl groups at well-defined binding sites; proposed mechanisms for these chemical groups are shown schematically (left to right, Fig. 4B inset). Methylene groups may form upon reaction with the hydroxyl group at the 6 position (Fig. 4B inset), which can react ten times faster than the other -OH groups (30). Further, carboxyl groups observed with XPS can form ester bonds with hydroxyl groups, which are stronger than the hydrogen bonds of the unmodified cellulose fibers. Low phosphorous concentrations (Fig. s2) and unchanged lattice parameters (Table s1) indicate far fewer links are made than hydrogen bonds broken. Indeed, probing the hydrogen-bond intensity in cellulose with FTIR absorbance ratios at different wavelengths, using the $\mathrm{C}-\mathrm{H}$ stretching band as an internal standard (31), shows a clear decrease number of intermolecular hydrogen bonds for LT (Methods, Table s2). This supports our claim that chemical cross-links through methyl, phosphate, and carboxyl bridges form at the expense of hydrogen bonding physical cross-links. This implies that the net strength is 
bioRxiv preprint doi: https://doi.org/10.1101/2021.09.22.461422; this version posted September 24, 2021. The copyright holder for this preprint

(which was not certified by peer review) is the author/funder. All rights reserved. No reuse allowed without permission.

Submitted Manuscript

September 2021

higher because of these tighter cross-links (Fig. 4B inset), which is confirmed by the higher average modulus (196.4 vs $134.6 \mathrm{MPa}$ ) for LT vs MC. The stabilization and improvement of mechanical properties with LT may therefore be attributed to disruption of intrinsic hydrogen bonds between cellulose chains at reactive hydroxyl, methyl and phosphate group sites, leading to an increased interaction between cellulose chains that effectively transfers and distributes applied stress. Additionally, the unprecedented flame retardance promoted by incorporation of phosphates may also be enhanced by the addition of methyl groups with lecithin tanning, which can decrease the rate of combustion by promoting cross-linking during pyrolysis.

\section{Coloration with Natural Dyes}

Color is a feature vital to the commercial success of textiles, and one which currently comes at a high cost of toxicity through use of synthetic dyes $(2,4)$. Natural dyeing is one of the most ancient of arts, dating back to 4000 BC Mesopotamia. Leveraging the high biosorption capability of $\mathrm{MC}$ (11), we color microbial biotextiles with natural dyes, including important historical dyes, such as madder, cochineal, and indigo, as well as extracted from waste, including discarded onion skins and nails, which provide tannins and iron acetate, respectively, that bind plant chromophores to cellulose and modify color (Fig. 5). Integration of the dye bath and culture media enables coloration during biosynthesis, eliminating the additional water and energy demands of dip dyeing (Fig. s6). Surface treatment with heated soy wax adds texture and water repellency to the biotextiles (Fig. 5.15-16, Movie s2). Surface design motifs, including texture and spatial control in coloration, utilizing ancient folding techniques, denoted Shibori and Hapa Zome in Japan and Adire in West Africa, are shown with our bioleather sneakers and wallet prototypes (Fig. 5.175.22).

\section{Ecological and Human Health Impacts of Microbial Biotextiles}

A cradle-to-gate life cycle impact assessment (LCA) is used to quantitatively compare the environmental and human health impacts of LT biotextiles and conventional textiles, including chrome-tanned leather, synthetic leather (polyurethane (PU)-coated polyester), and cotton canvas (Fig. 6). For direct comparison, normalization (32) and weighting factors (33) are used to convert the manufacturing impacts across eleven categories into a single score in units of milliPoints $(\mathrm{mPts}) / \mathrm{m}^{2}$ of textile (Table s3); one point $(\mathrm{Pt})$ represents an average individual's annual share of the total environmental impact in the United States. LT biotextiles biosynthesized in the lab or processed from by-products are denoted biotextileLAB and biotextileBP, respectively.

LCA reveals an $85 \%$ improvement in environmental performance for biotextile LAB over cow leather (Fig. 6A). The improvement is largely due to mitigation of the human toxicity impacts of chrome-tanning, specifically carcinogenics accounting for $94.8 \%$ of leather's total impact (1.81 of $1.91 \mathrm{mPts}$, Fig. 6A, Table s3). Notably, because the Ecoinvent data for leather assumes hides are a by-product of milk and meat production, the assessment does not include the large climate impacts of the livestock industry, such that leather shows a minimal carbon footprint $\left(0.6 \mathrm{~kg} \mathrm{CO} 2^{-}\right.$ $\mathrm{eq} / \mathrm{m}^{2}$ ) compared to the other textiles.

Microbial biotextiles mitigate the climate emissions produced in the manufacture of conventional textiles $\left(0.9 \mathrm{CO}_{2} \mathrm{~kg}\right.$-eq $/ \mathrm{m}^{2}$ for biotextile $\mathrm{LAB}$ compared with 11.4 and $5.7 \mathrm{~kg} \mathrm{CO} 2 \mathrm{~kg}$ $\mathrm{eq} / \mathrm{m}^{2}$, for synthetic (PU) leather and cotton, respectively). Human toxicity, although one hundred times lower than that of cow leather, is the largest impact category for LT produced by microbial biosynthesis (biotextile $\mathrm{LAB}$ ), due to carcinogenics and hormonally active agents produced in refinery processes for sugar used as a carbon source in the fermentation media (Fig. 6B). 
bioRxiv preprint doi: https://doi.org/10.1101/2021.09.22.461422; this version posted September 24, 2021. The copyright holder for this preprint

(which was not certified by peer review) is the author/funder. All rights reserved. No reuse allowed without permission.

Submitted Manuscript

September 2021

To investigate the potential benefit of waste-to-resource strategies, biotextiles were also produced from MC obtained as a by-product of commercial kombucha production (biotextile $\mathrm{BP}$, Fig. 6, Table s7). After purification and lecithin treatment, biotextilesp displayed high tensile strength and ductility, comparable to average values for biotextile LAB (Fig. s7). Elimination of the agricultural impacts of the sugar and tea used as carbon and nitrogen sources for microbial fermentation led to a $67 \%$ environmental performance improvement for biotextile $\mathrm{BP}$ compared to biotextile $\mathrm{LAB}$ (Table s4). Notably, biotextileBP mitigates the toxicity impacts of cow leather by a factor of $10^{3}$, and the carbon footprint of synthetic leather by $97 \%\left(0.37 \mathrm{vs} 11.38 \mathrm{~kg} \mathrm{CO}\right.$-eq. $\left./ \mathrm{m}^{2}\right)$. Since the media accounts for 30-65\% of the cost of MC production (34-35), and, here, $66 \%$ of the environmental impacts (Fig. 6, Table s7), utilization of waste streams to extract nutrients for the biosynthesis, and as a source of MC itself, opens opportunities for regenerative, performance biotextiles with both economic and environmental benefit at scale.

Finally, we compare biocoloration of cellulose-based textile $\left(400 \mathrm{~g}, 1 \mathrm{~m}^{2}\right)$ yellow onion skins, obtained as food by-product/waste (Fig. 5.7), with impacts associated with synthetic dyeing and finishing. This simple natural process eliminates $348.13 \mathrm{~kg}$ TEG ecotoxicity, $0.18 \mathrm{~kg} \mathrm{C} 2 \mathrm{H}_{3} \mathrm{Cl}$ eq. human toxicity, and $5.4 \mathrm{~kg} \mathrm{CO}$-eq. of climate impacts from synthetic dyeing and finishing, based on data from Murugesh et. al. (36). These findings underscore the benefits of merging microbial biosynthesis and waste-to-resource strategies for a circular materials economy.

\section{Biodegradation in Natural Terrestrial Environment}

Disposal of leather and synthetic leather waste is a serious problem as both are nonbiodegradable by microorganisms, while land co-disposal and incineration produce greenhouse gases and introduce carcinogens and other toxins to the ecosystem. In contrast, MC is expected to degrade once exposed to environments rich with cellulolytic microorganisms that hydrolyze the $\beta$-1,4-glycosidic linkages of cellulose. To investigate environmental degradability of LT biotextiles, samples $(n=5)$ were weighed and buried at a depth of at least $2.5 \mathrm{~cm}$ in tested, nutrient rich soil. After 60 days, with temperatures between $14.2^{\circ}$ and $3.2^{\circ} \mathrm{C}$, LT showed significant visible deterioration, crumbled easily, and had lost $74.45 \pm 2.94 \%$ of the initial mass in the natural environment (Table s8). The data confirms that MC-based products may rapidly reenter the ecosystem, where they may promote the $\mathrm{CO}_{2}$ capture potential of healthy soil.

\section{Conclusions and Future Outlook}

We harness microbial biofabrication of nanocellulose and adapt ancient textile techniques to inform the development of sustainably engineered, colored biotextiles with a circular life cycle. The unique molecular self-organization of $\mathrm{MC}$ is combined with bio-phosphorylation to create bioleather with high tensile strength, ductility and outstanding flame retardance. This biofabrication approach eliminates the use of hazardous substances, such as chromium VI derivatives for tanning, halogen compounds for fire-retardancy, phthalates as plasticizers, and azo dyes for color. Life cycle assessment quantifies up to an order of magnitude reduction in total environmental damage for lecithin-treated biotextiles relative to conventional textile manufacture, and highlights how use of waste-to-resource strategies can further mitigate impacts. In particular, our bioleather prototypes mitigate the toxicity of chrome-tanned leather by a factor of $10^{3}$ and the carbon footprints of synthetic leather and cotton by $\sim 97 \%$.

Future prospects include MC-based alternatives to cotton and synthetic fibers as well as conductive, biomedical and sensor textiles (37). Beyond textiles, phosphorylated biopolymers, including MC, show high performance for diverse applications, from heavy metal pollution remediation to tissue cell engineering and bone regeneration (38), but the many potential benefits are offset by the toxicity and non-renewability of reagents and high temperatures of conventional 
bioRxiv preprint doi: https://doi.org/10.1101/2021.09.22.461422; this version posted September 24, 2021. The copyright holder for this preprint

(which was not certified by peer review) is the author/funder. All rights reserved. No reuse allowed without permission.

Submitted Manuscript

September 2021

phosphorylation processes. The lecithin process developed here may therefore help meet the challenge of developing efficient green manufacturing routes for biopolymers to realize their full potential in a regenerative bioeconomy.

The translational potential of $\mathrm{MC}$ is tremendous, as the use of microbes to direct biomaterial formation in a bottom-up process to fabricate high performance products can strategically eliminate the toxicity, water and plastic pollution, and climate impacts of traditional manufacturing processes. Thus, advances in microbial cellulose performance incentivizes a transition to a circular economy, characterized by rapidly renewable resources, waste-to-resource strategies, low impact processes, scalability, and biodegradability.

\section{References}

1. M. A. Altieri, Ecological impacts of industrial agriculture and the possibilities for truly sustainable farming. Monthly Review 50, 3 (1998)

2. S. S. Muthu, Assessing the Environmental Impact of Textiles and the Clothing Supply Chain (Woodhead Publishing, 2nd Edition. 2020).

3. P. Chrobot, M. Faist, L. Gustavus, A. Martin, A. Stamm, R. Zah, M. Zollinger, "Measuring fashion: Insights from the environmental impact of the global apparel and footwear industries study" (Quantis, 2018; https://quantis-intl.com/wpcontent/uploads/2018/03/measuringfashion_globalimpactstudy_fullreport_quantis_cwf_2018a.pdf).

4. World Bank, "The Bangladesh responsible sourcing initiative: A new model for green growth?” (World Bank, 2014; https://openknowledge.worldbank.org/handle/10986/20764).

5. Institution of Mechanical Engineers, "Engineering out of fashion waste" (Institution of Mechanical Engineers, 2018; https://www.imeche.org/policy-andpress/reports/detail/engineering-out-fashion-waste).

6. Ellen MacArthur Foundation, "A new textiles economy: redesigning fashion's future" (Ellen MacCarthur Foundation Report, 2017).

7. G. L. Tadesse, T. K. Guya, Impacts of tannery effluent on environments and human health. Environ. 7, 3 (2017).

8. Y. Deng, Y. Zhang, B. Lemos, H. Ren, Tissue accumulation of microplastics in mice and biomarker responses suggest widespread health risks of exposure. Sci Rep 7, 46687 (2017).

9. A. Ragusa, A. Svelato, C. Santacroce, P. Catalano, V. Notarstefano, O. Carnevali, F. Papa, M. C. A. Rongioletti, F. Baiocco, S. Draghi, E. D'Amore, D. Rinaldo, M. Matta, E. Giorgini, Plasticenta: First evidence of microplastics in human placenta. Environ. Int. 146, 106274 (2021).

10. J. Hildebrandt, D. Thrän, A. Bezama, The circularity of potential bio-textile production routes: Comparing life cycle impacts of bio-based materials used within the manufacturing of selected leather substitutes, J. Clean. Prod. 287,125470 (2021).

11. M. Gama, P. Gatenholm, D. Klemm, Ed., Bacterial NanoCellulose: A Sophisticated Multifunctional Material (CRC Press, 2012).

12. K.Y. Lee, G. Buldum, A. Mantalaris, A. Bismarck, More than meets the eye in bacterial cellulose: biosynthesis, bioprocessing, and applications. Macromol. Biosci. 14, 10-32 (2014).

13. G. Chen, G. Wu, L. Chen, W. Wang, F. F. Hong, L. J. Jönsson, Comparison of productivity and quality of bacterial nanocellulose synthesized using culture media based on seven sugars from biomass. Microb. Biotechnol. 12, 677-687 (2019). 
bioRxiv preprint doi: https://doi.org/10.1101/2021.09.22.461422; this version posted September 24, 2021. The copyright holder for this preprint (which was not certified by peer review) is the author/funder. All rights reserved. No reuse allowed without permission.

Submitted Manuscript

September 2021

14. Q. Li, S. McGinnis, C. Sydnor, A. Wong, S. Renneckar, Nanocellulose life cycle assessment. ACS Sustainable Chem. Eng. 1, 919-928 (2013).

15. Í. Donini, D. De Salvi, F. Fukumoto, W. Lustri, H. Barud, R. Marchetto, Y. Messaddeq, S. Ribeiro, Biosynthesis and recent advances in production of bacterial cellulose. Ecl. Quím. 35, 165 - 178 (2010).

16. K. Kamiński, M. Jarosz, J. Grudzień, J. Pawlik, F. Zastawnik, P. Pandyra, A. M. Kołodziejczyk, Hydrogel bacterial cellulose: a path to improved materials for new ecofriendly textiles. Cellulose. 27, 5353-5365 (2020).

17. B. A. Howell, S. T. Lazar, Biobased Plasticizers from glycerol/adipic acid hyperbranched poly(ester)s, Ind. Eng. Chem. Res. 58, 37, 17227-17234 (2019).

18. A. G. Püntenera, S. Moss, Ötzi, the Iceman and his leather clothes. Chimia. 64, 315-320 (2010).

19. C. L. Heth, "The Skin They Were In: Leather and Tanning in Antiquity" in Chemical Technology in Antiquity (ACS Symposium Series 1211, 2015), pp. 181-196.

20. S. Park, J.O. Baker, M.E. Himmel, P.A. Parilla, D. K. Johnson, Cellulose crystallinity index: measurement techniques and their impact on interpreting cellulase performance. Biotechnol. Biofuels. 3, (2010).

21. S. Zhang, S.N. Li, Q. Wu, Q. Li, J. Huang, W. Li, W. Zhang, S. Wang, Phosphorus containing group and lignin toward intrinsically flame-retardant cellulose nanofibril-based film with enhanced mechanical properties. Compos. B. Eng. 212, 108699 (2021).

22. C.M. Butt, J. Congleton, K. Hoffman, M. Fang, H. M. Stapleton, Metabolites of organophosphate flame retardants and 2-Ethylhexyl tetrabromobenzoate in urine from paired mothers and toddlers. Environ. Sci. Technol. 48, 10432-8 (2014).

23. G. Montaudo, E. Scamporrino, D. Vitalini, The effect of ammonium polyphosphate on the mechanism of thermal degradation of polyureas. J. Polym. Sci., Polym. Chem. Ed. 21, 3361(1983).

24. W. Wang, Y. Kan, H. Pan, Y. Pan, B. Li, K.M. Liew, Y. Hu, Phosphorylated cellulose applied for the exfoliation of LDH: An advanced reinforcement for polyvinyl alcohol. Compos. Part A Appl. Sci. Manuf. 94, 170-177 (2017).

25. E.H. Ablouh, F. Brouillette, M. Taourirte, H. Sehaqui, M. El. Achaby, A. Belfkira, A highly efficient chemical approach to producing green phosphorylated cellulosic macromolecules. $R S C A d v .11,24206-24216$ (2021).

26. M. Ghanadpour, B. Wicklein, F. Carosio, L. Wågberg, All-natural and highly flame-resistant freeze-cast foams based on phosphorylated cellulose nanofibrils. Nanoscale 10, 4085-4095 (2018).

27. D. M. Suflet, G. C. Chitanu, V. I. Popa, Phosphorylation of polysaccharides: New results on synthesis and characterisation of phosphorylated cellulose. React. Funct. Polym. 66, 11, 1240-1249 (2006).

28. N. Zhu, F.Z. Cui, K. Hu, L. Zhu, Biomedical modification of poly(L-lactide) by blending with lecithin, J. Biomed. Mater. Res. 82A, 455-461 (2007).

29. M. Fan, D. Dai, B. Huang, " Fourier transform infrared spectroscopy for natural fibres” in Fourier transform-materials analysis (Dr Salih Salih (Ed.), 2012), pp. 45-68.

30. A. Hebeish, J. T. Guthrie, The Chemistry and Technology of Cellulose Copolymers: Polymers - Properties and Applications 4 (Springer-Verlag, 1981).

31. H. Guo, M. He, R. Huang, W. Qi, W. Guo, R. Su, Z. He, Changes in the supramolecular structures of cellulose after hydrolysis studied by terahertz spectroscopy and other methods. RSC. Adv. 4, 57945 (2014). 
bioRxiv preprint doi: https://doi.org/10.1101/2021.09.22.461422; this version posted September 24, 2021. The copyright holder for this preprint (which was not certified by peer review) is the author/funder. All rights reserved. No reuse allowed without permission. Submitted Manuscript September 2021

32. M. Ryberg, M. Vieira, M. Zgola, J. Bare, R. Rosenbaum, Updated US and Canadian normalization factors for TRACI 2.1. Clean Techn. Environ. Policy. 16, 329-339 (2014).

33. T.P. Gloria, B.C. Lippiatt, J. Cooper, Life cycle impact assessment weights to support environmentally preferable purchasing in the United States. Environ. Sci. Technol. 41, 21, 7551-7557 (2007).

34. K. B. Murugesh, M. Selvadass, Life cycle assessment for the dyeing and finishing process of organic cotton knitted fabrics, JTATM. 8, 2 (2013).

35. B. V. Mohite, S. V. Patil, A Novel, Biomaterial: Bacterial Cellulose and its New Era Applications. Biotech. Appl. Bioc. 61, 101-110 (2014).

36. N. Illy, M. Fache, R. Ménard, C. Negrell, S. Caillolc, G. David, Phosphorylation of bio-based compounds: the state of the art. Polym. Chem. 6, 6257-6291 (2015).

37. X. Li, Y. Wang, J. Li, B. Shi, Effect of Sodium Chloride on Structure of Collagen Fiber Network in Pickling and Tanning. JALCA 111, 6, 203-237 (2016).

Acknowledgments: We thank OM Champagne Tea (Mount Kisco, NY) for donations of microbial nanocellulose, produced as a fermentation by-product of commercial kombucha beverage production.

\section{Funding:}

National Science Foundation, MRSEC program through Columbia in the Center for Precision Assembly of Superstratic and Superatomic Solids, grant DMR-1420634 (TNS, RA, Y-TC, CTJ, SE, DA, STR).

National Institutes of Health, grant NIH-NIAMS 1R01-AR07352901 (RA, Y-TC, HHL).

DoD CDMRP award, grant W81XWH- 15-1-0685 (RA, Y-TC, HHL).

\section{Author contributions:}

Conceptualization: TNS, RA, HHL

Methodology: TNS, RA, DF, Y-TC, GM, KGS, AMVC, SG, AC, HHL

Investigation: TNS, RA, STR, DA, SE, Y-TC, CTJ

Visualization: TNS, RA, DF, HHL

Funding acquisition: TNS, HHL

Project administration: JLS, EH

Supervision: TNS, HHL, SG, AMVC, CN, SKK

Writing - original draft: TNS, RA, DF, HHL

Writing - review \& editing: TNS, RA, DF, Y-TC, GWS, GM, DA, STR, AC, SG, SKK, HHL

Competing interests: Authors declare that they have no competing interests.

Data and materials availability: All data are available in the main text or the supplementary materials.

\section{Supplementary Materials}

Materials and Methods

Supplementary Text

Figs. S1 to S6

Tables S1 to S8

References (1-12)

Movies S1 to S2 


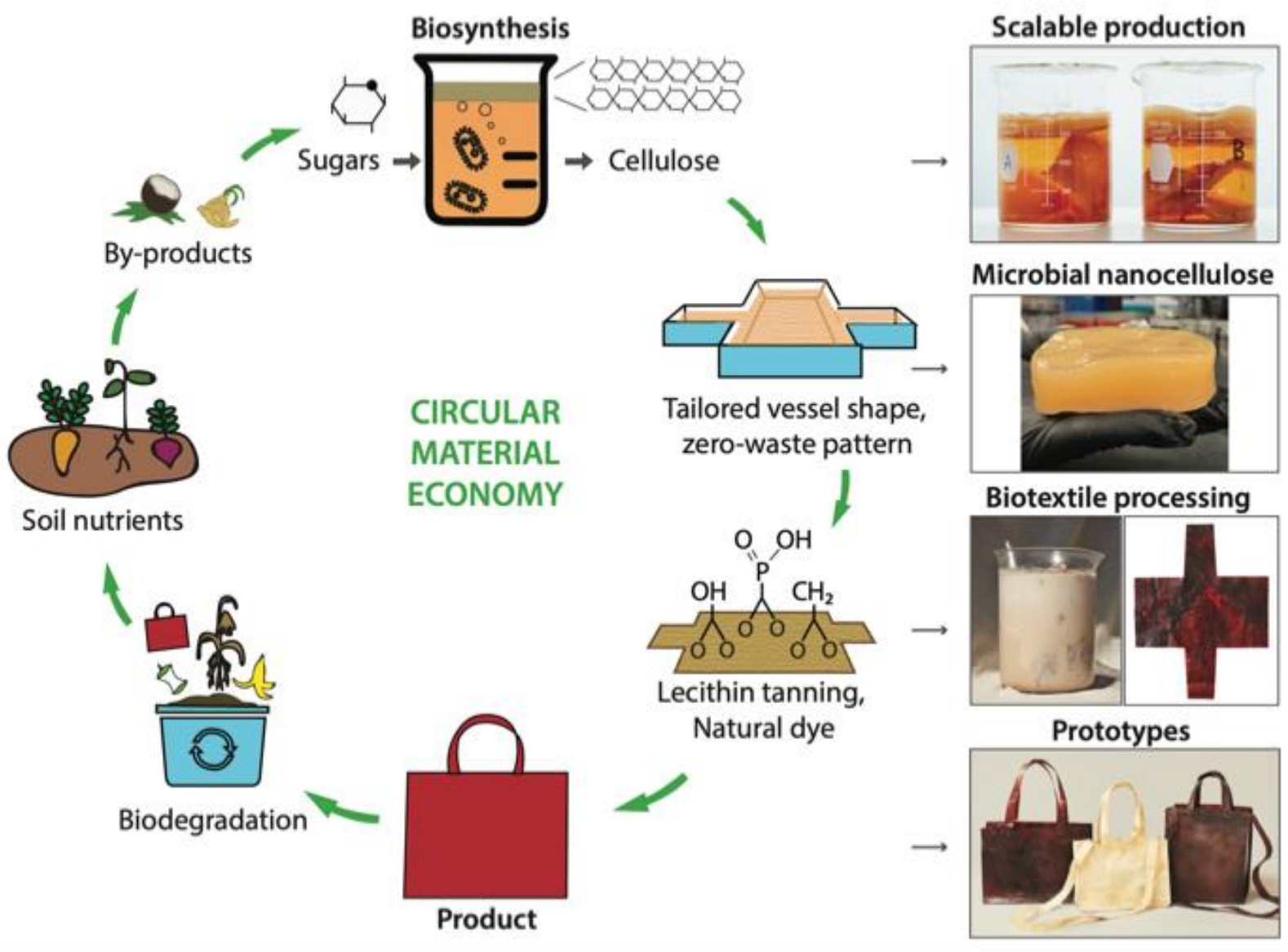

Fig. 1. Potential of microbial biosynthesis and processing based in green chemistry to create minimal waste products with a closed loop life cycle (left). Right panel: Process photos for biosynthesis and processing of MC biotextiles for the schematic diagram on left, showing: scalable production of microbial nanocellulose from a variety of carbon sources, including fructose (beaker A) and sucrose (beaker B) and green chemistry processing--lecithin tanning and natural dye coloration--of biotextiles grown to the geometry of a bag pattern, to create low impact, minimal waste products, such as our bioleather bag prototypes, that meet design criteria of performance and biodegradability for a regenerative, circular materials economy. 
bioRxiv preprint doi: https://doi.org/10.1101/2021.09.22.461422; this version posted September 24, 2021. The copyright holder for this preprint (which was not certified by peer review) is the author/funder. All rights reserved. No reuse allowed without permission. Submitted Manuscript

September 2021
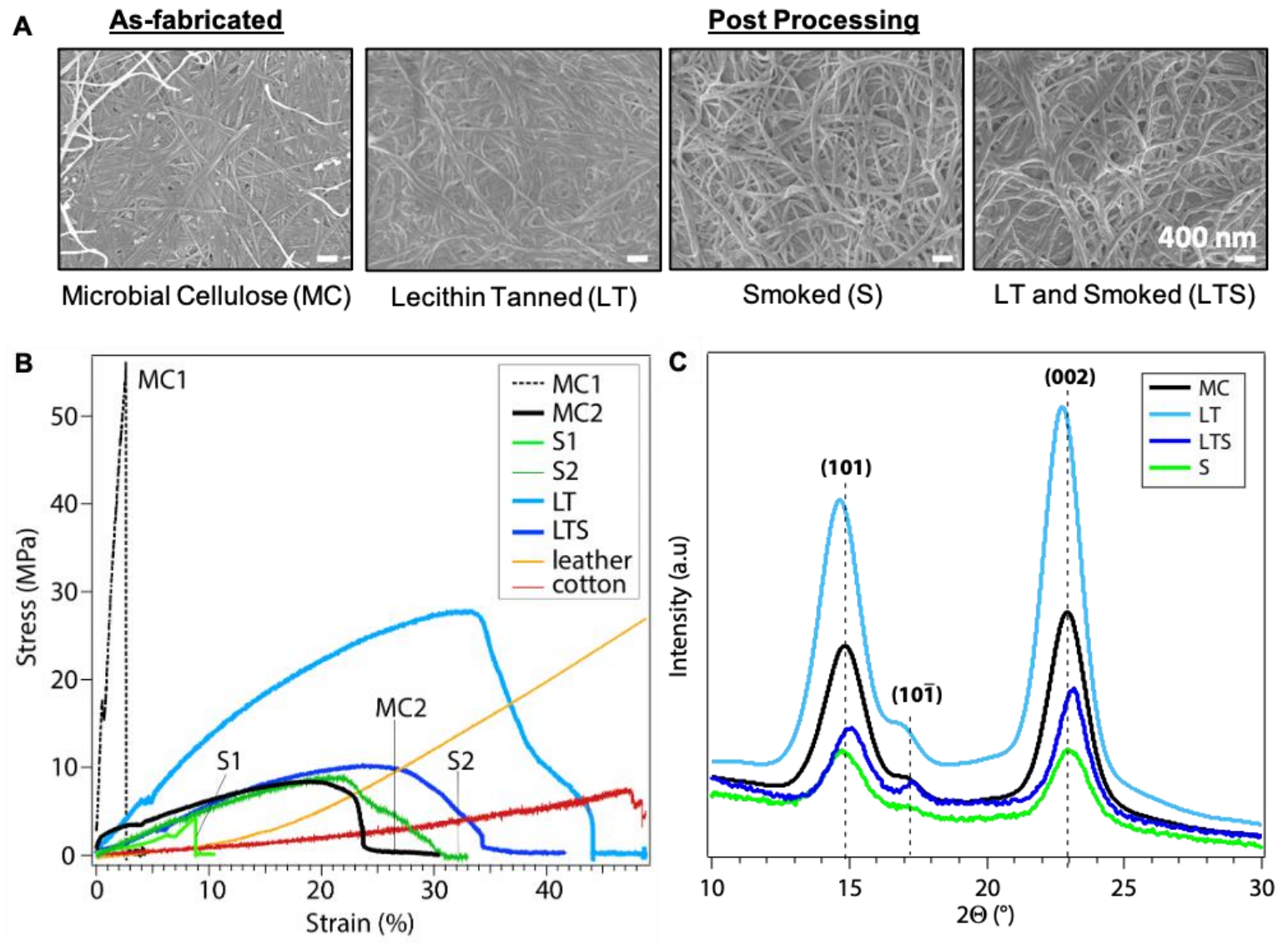

Fig. 2. Physiochemical Characterization of Microbial Cellulose Biotextiles. (A) SEM micrographs ; (B) tensile properties; and (C) XRD data; for as grown microbial cellulose (MC) and microbial treated by lecithin (LT) and/or smoke tanning (LTS, S). MC1 and MC2 and S1 and $\mathrm{S} 2$ were produced from the same biosynthesis and processing conditions; the variation reflects the influence of MC hygroscopicity on mechanical properties which is overcome with lecithin tanning 
(LT).

\begin{tabular}{|c|c|c|c|c|c|c|}
\hline & $\begin{array}{c}\text { Young's } \\
\text { Modulus } \\
\text { (MPa) } n=4\end{array}$ & $\begin{array}{c}\text { Toughness } \\
\begin{array}{c}\text { (MPa) } \\
n=4\end{array}\end{array}$ & $\begin{array}{c}\text { Max. } \\
\text { Strength } \\
(\mathrm{MPa}) \mathrm{n}=4\end{array}$ & $\begin{array}{c}\text { Fiber } \\
\text { Diameter } \\
(\mathrm{nm}) \mathrm{n}=100\end{array}$ & $\begin{array}{c}\text { Crystallinity } \\
\text { Index (\%) } \\
n=5\end{array}$ & WCA $\left({ }^{\circ}\right) n=5$ \\
\hline MC1 & $210.9 \pm 58.6$ & $2.5 \pm 0.6$ & $17.4 \pm 4.6$ & \multirow{2}{*}{$71.0 \pm 19.0$} & \multirow{2}{*}{$84.12 \pm 0.03$} & \multirow{2}{*}{$61.9 \pm 12.4$} \\
\hline MC2 & $58.30 \pm 35.7$ & $2.44 \pm 1.4$ & $12.0 \pm 5.8$ & & & \\
\hline LT & $196.4 \pm 65.4$ & $7.2 \pm 2.3$ & $27.9 \pm 1.8$ & $69.4 \pm 16.8$ & $87.19 \pm 0.07$ & $46.5 \pm 10.9$ \\
\hline LTS & $89.8 \pm 45.2$ & $2.2 \pm 0.3$ & $11.1 \pm 1.5$ & $76.5 \pm 16.2$ & $77.00 \pm 0.04$ & $46.1 \pm 6.2$ \\
\hline s1 & $38.9 \pm 19.1$ & $0.1 \pm 0.05$ & $3.4 \pm 1.5$ & \multirow{2}{*}{$56.6 \pm 14.7$} & \multirow{2}{*}{$67.51 \pm 0.04$} & \multirow{2}{*}{$58.4 \pm 7.0$} \\
\hline S2 & $24.0 \pm 3.3$ & $1.5 \pm 1.0$ & $5.5 \pm 2.8$ & & & \\
\hline cotton & 19.7 & 2.6 & 8.0 & $1.27 \pm 0.3$ E04 & - & - \\
\hline leather & 75.9 & 5.4 & 28.4 & 10 E04* & - & - \\
\hline
\end{tabular}

Table 1. Physiochemical properties of as-fabricated and treated biotextiles compared to cotton and leather. Mechanical properties, including Young's Modulus, Toughness and Max Strength $(n=4)$, crystallinity index obtained from $x$-ray diffraction, fiber diameter $(n=100)$, and water contact angle (WCA, $\mathrm{n}=5)$ ) for as-fabricated $(\mathrm{MC})$ and processed (LT, S, LTS) for samples shown in Fig. 2. *Fiber diameter for leather based on published data (1). ${ }^{\wedge}$ indicates significance between groups $(\alpha=0.05, \mathrm{n}=5$ ). All quantitative values are reported as means \pm standard deviation, with $\mathrm{n}$ equal to the number of replicates per group, with significance was attained at $\mathrm{p}<0.05$. 

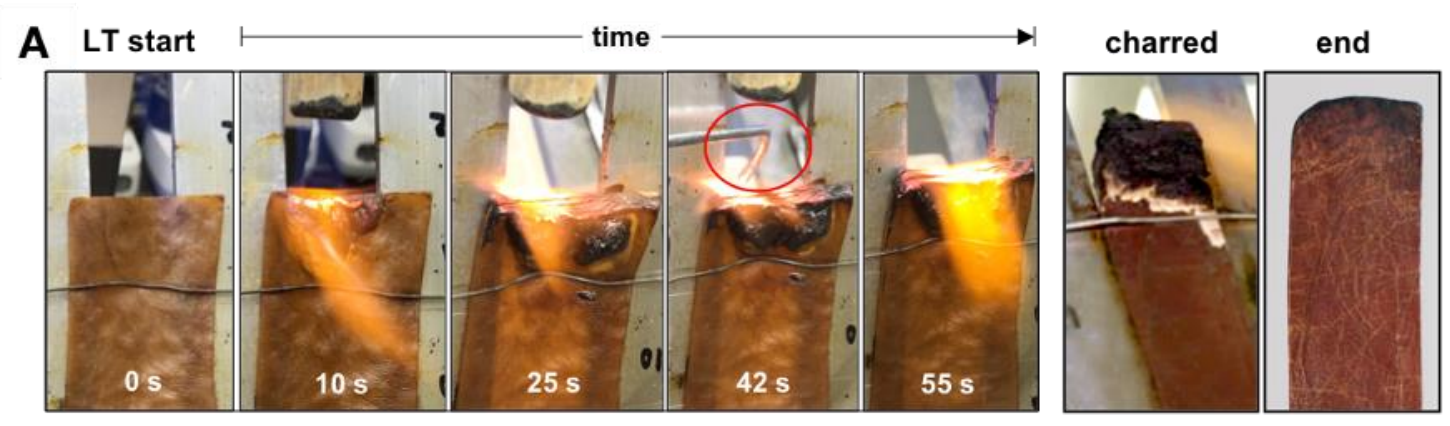

B

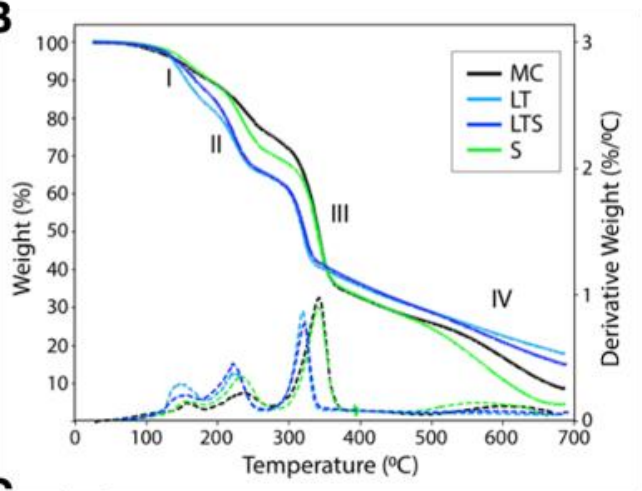

\begin{tabular}{|ccccc|}
\hline $\begin{array}{c}\text { Sample } \\
(\mathrm{n}=5)\end{array}$ & \multicolumn{3}{c}{$\begin{array}{c}\text { Mass Loss } \\
(\%)\end{array}$} & $\begin{array}{c}\text { Mass at } \\
680^{\circ} \mathrm{C}(\%)\end{array}$ \\
\hline Region & Hydration & \multicolumn{2}{c|}{ Combustion Pathway } & Char \\
\cline { 2 - 5 } & I & II & III & IV \\
\hline MC & $5.4 \pm 0.9$ & $17.0 \pm 2.4$ & $49.5 \pm 1.2$ & 9.0 \\
LT & $8.5 \pm 0.3$ & $29.6 \pm 0.3$ & $59.0 \pm 0.6$ & 18.2 \\
S & $4.2 \pm 0.9$ & $19.9 \pm 3.8$ & $50.4 \pm 1.5$ & 4.6 \\
LTS & $6.3 \pm 1.4$ & $28.6 \pm 2.6$ & $57.8 \pm 1.2$ & 15.5 \\
\hline
\end{tabular}

C

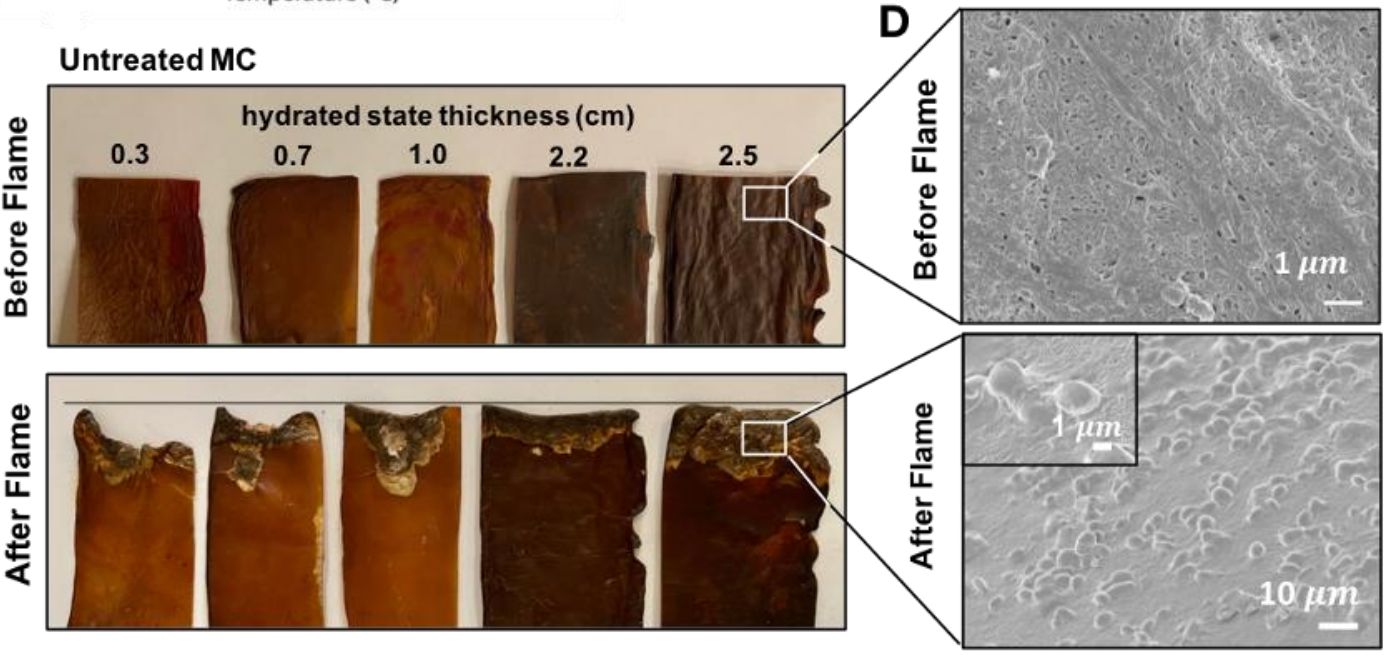

Fig. 3. Flame Retardance of Microbial Cellulose Biotextiles. (A) Under a $2054^{\circ} \mathrm{C}$ flame, lecithin tanned microbial cellulose (LT) does not ignite and deflects the flame from the surface, while an aluminum brazing rod introduced at 39 seconds promptly melts under the flame. After repeated exposure until char formation is observed (charred), LT biotextiles remain intact under the surface ash (end). (B) Thermal decomposition analysis (TGA) curves (left) and data (right) of as-fabricated (MC) and treated (LT, S, LTS) biotextiles under nitrogen atmosphere shows the phospholipid treatment directs the combustion chemistry toward ash formation over the glucosan formation to promote flame retardance. $(\mathbf{C})$ The nanofiber morphology and layered microstructure of as-fabricated MC biosynthesized to sufficient thickness $(2.5 \mathrm{~cm}$ in hydrated state) also demonstrates flame retardance, evidence by resistance to material lost to combustion. (D) SEM 
bioRxiv preprint doi: https://doi.org/10.1101/2021.09.22.461422; this version posted September 24, 2021. The copyright holder for this preprint (which was not certified by peer review) is the author/funder. All rights reserved. No reuse allowed without permission.

\section{Submitted Manuscript}

September 2021

micrograph showing surface morphology before (top) and in charred region after (bottom) flame testing; the torched region of the latter shows a morphology typical of a flame-retardant material.

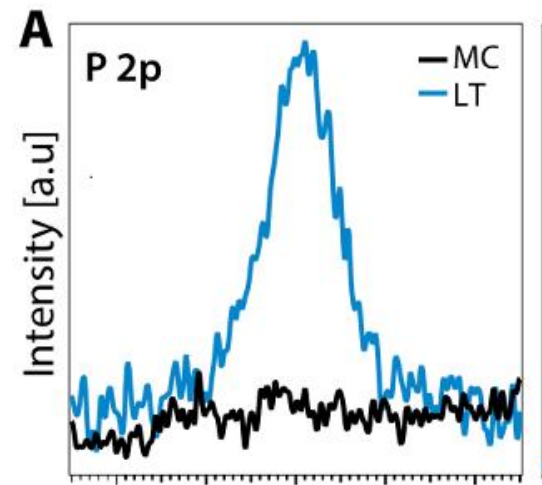

$138 \quad 136 \quad 134 \quad 132 \quad 130$ Binding Energy [eV]

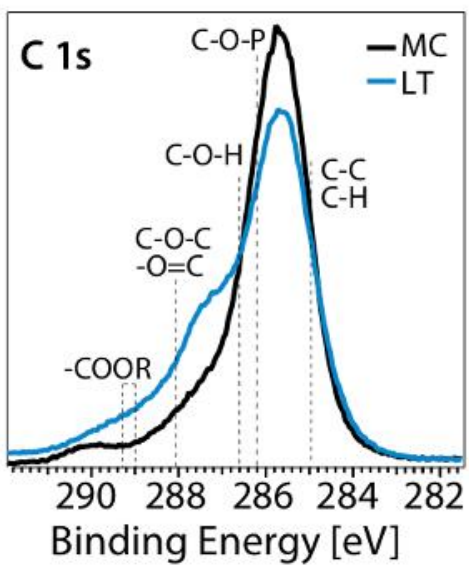

Binding Energy [eV]

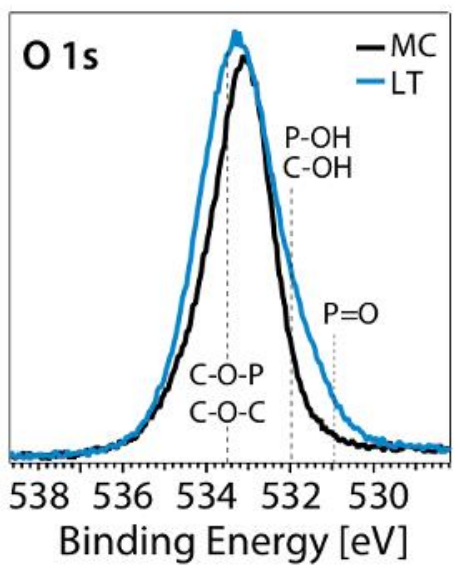

\section{B}

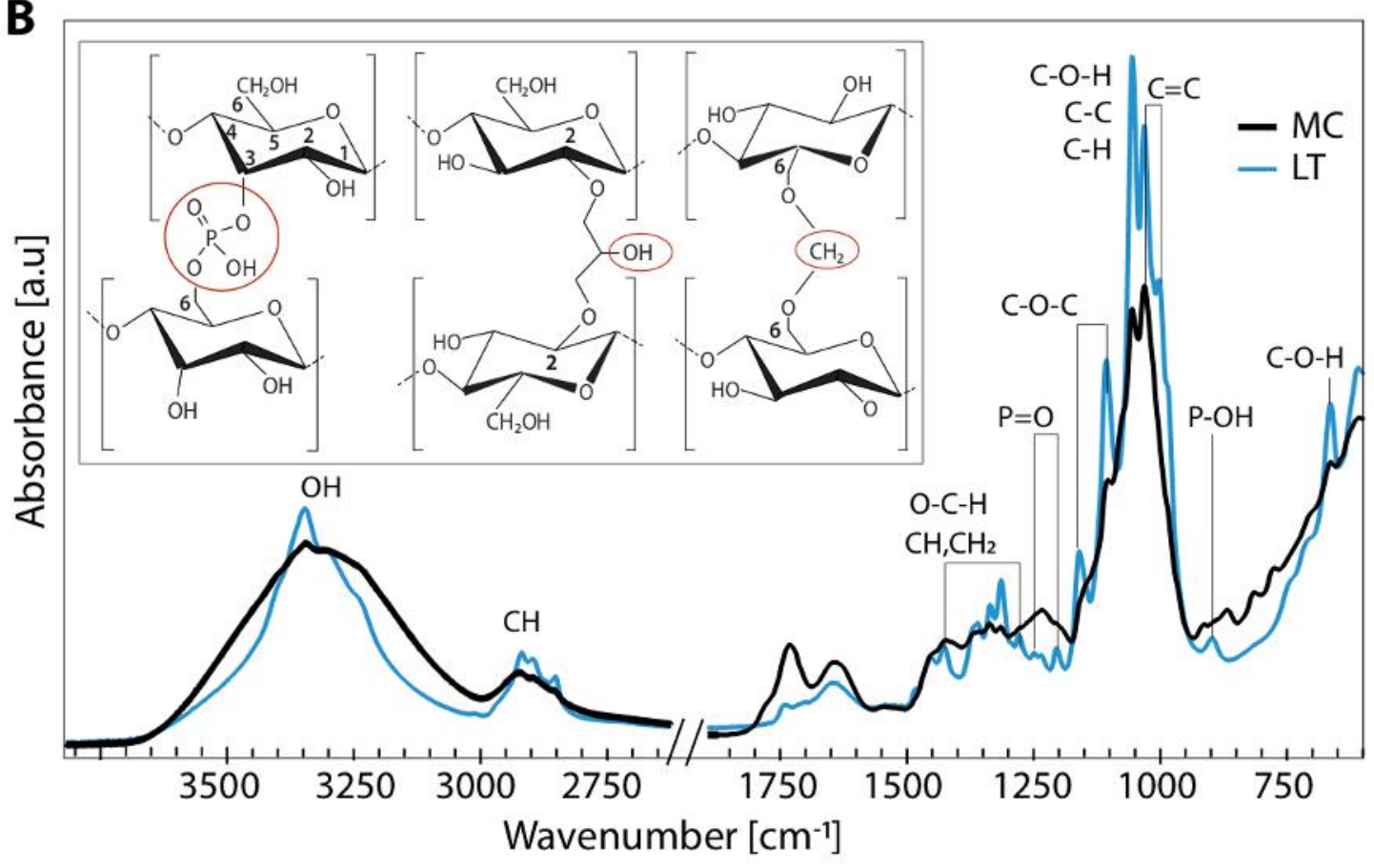

Fig. 4. Molecular-Level Chemical Analysis. A) X-ray photoelectron spectroscopy (XPS) and (B) Fourier Transform Infrared (FTIR) spectra of microbial cellulose textiles before (MC) and after lecithin tanning (LT). Inset: schematic depiction of proposed cross-linking mechanism with phosphate, methylene and carboxyl group bridges (left to right) for LT. 

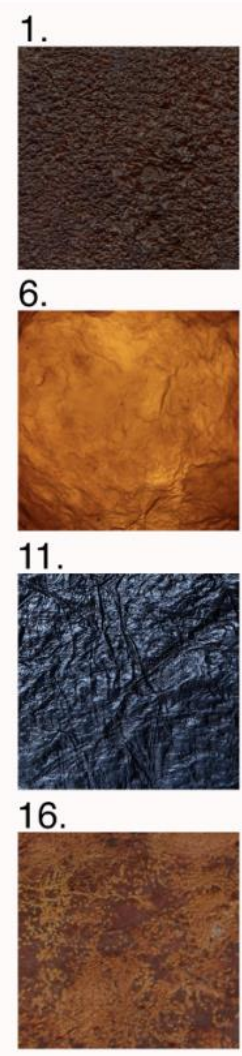

21.
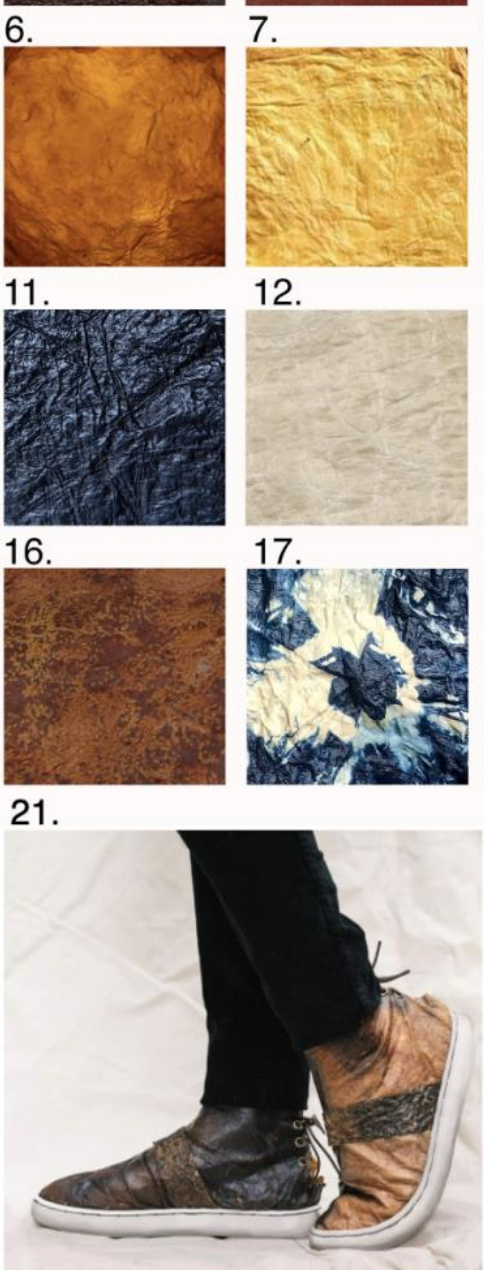

12.

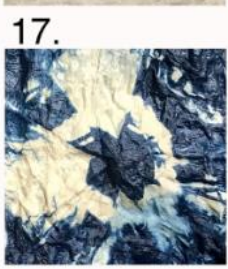

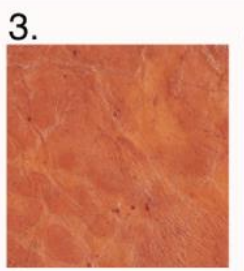

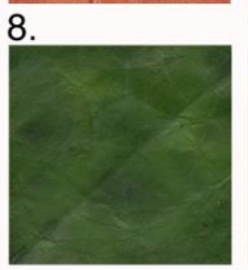

13.

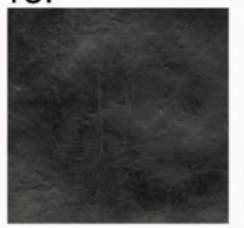

18.

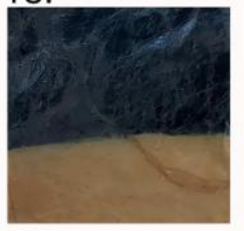

22.

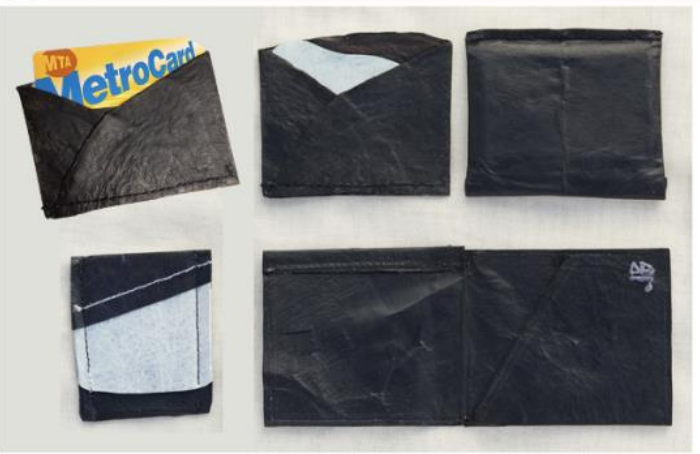

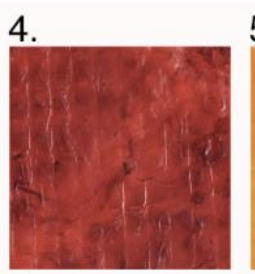
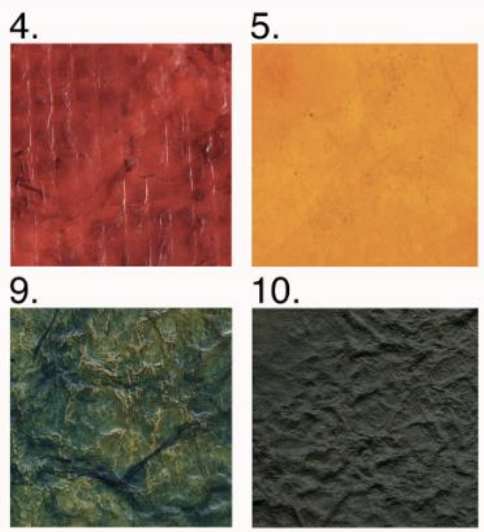

14.

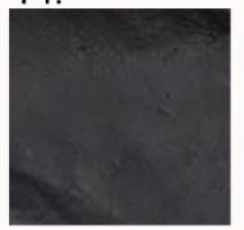

19.

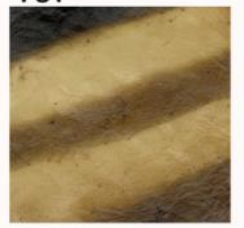

20.

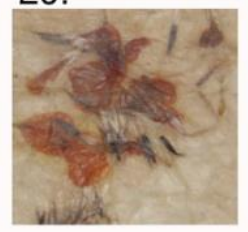

15.

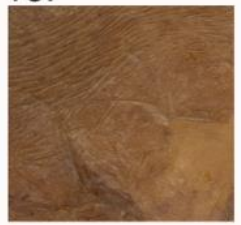

Fig. 5. Natural Dye Color Palette on Microbial Biotextiles. (1-3) madder root; (4) cochineal, (5) marigold; (6) turmeric; (7) onion skins; (8) chlorophyll; (9); indigo after one (9), three (10) and six (11) dips; (12) brown color removed by $0.5 \mathrm{M} \mathrm{NaOH}$ soak; black created by chemical interaction of tannic acid from black tea with iron acetate, extracted from discarded nails (13); and myrobalan overdyed with logwood and dipped in iron acetate (14); (15-16) as-fabricated MC treated with texture created by application of soy wax heated to 80C. Control of color modulation through: Shibori/Adire folding techniques (17); and partial submergence of biotextile in indigo vat (18). (19) Dark stripes obtained by chemical interaction of iron acetate and tannic acid on asfabricated MC; and (20) marigold flowers embedded between MC pellicle layers before drying, adapted from Japanese Hapa Zome techniques, showing design opportunities such as no sew seams offered by the layered structure of the moldable biotextile. Design prototypes, including (21) sneakers in natural color and an upcycled rubber sole; and (22) bioleather wallets with natural black as in (14) before lecithin tanning and drying and with white as in (12). See Methods for details. 

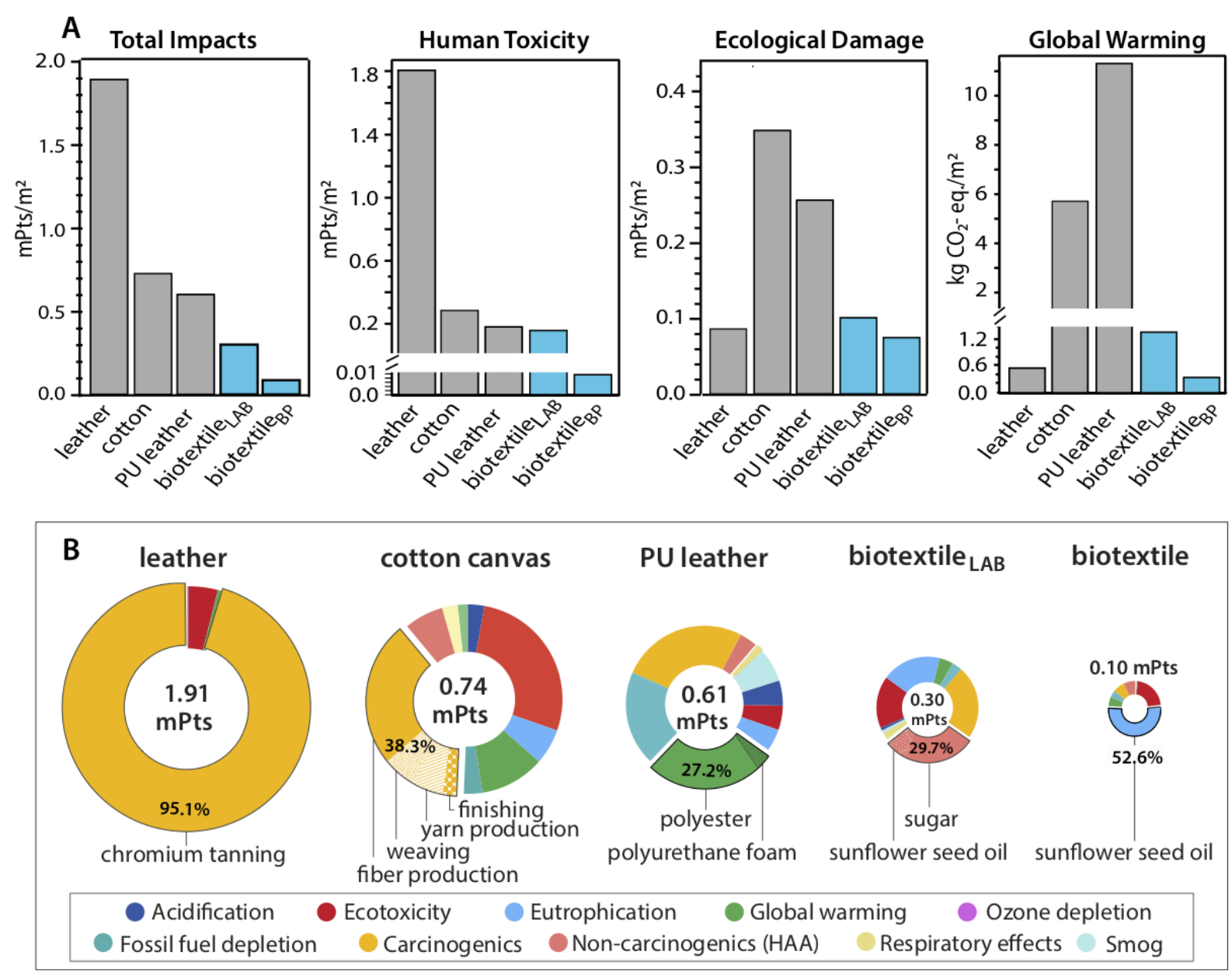

Fig. 6. Life Cycle Impact Assessment (LCA) of Microbial Cellulose Biotextiles. Cradle to gate LCA for the industrial manufacture of $1 \mathrm{~m}^{2}$ of conventional textile, including cow leather, synthetic leather (PU textile (polyurethane-coated polyester), and woven cotton, compared with laboratory-scale biofabrication (mirobial fermentation and lecithin processing) of $\mathrm{MC}$ (biotextile $\mathrm{LAB}$ ), and biotextiles processed (purified and lecithin tanned) from MC obtained as SCOBY by-product of commercial kombucha beverage production (biotextileвP). (A) Comparison of environmental impact categories for the different textiles. (B) Contributions to total impacts from different impacts categories (legend) and source of largest impacts. 